\title{
다난 \\ Luis Ferando Rojas: Visual Chronicler of Chile 1875 - 1942: \\ Illustration as a communicative tool and the problems of technological obsolescence
}

\author{
Carola Ureta Marin / Escuela de Diseno / Santiago / Chile
}

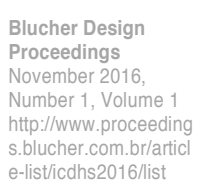

\begin{abstract}
This paper discusses a selection of the work of Luis Fernando Rojas, arguably Chile's most important illustrator and illustrated reporter between 1875-1942; who depicted not only what was happening in Chile, but also international events. At the time, photography was used for portrait work or landscapes, and rarely applied to daily life, so the drawings were the way to communicate. It seems paradoxical that the father of the cutting-edge technique of lithography in Chile would see himself directly affected by technological innovation and the modernisation of publishing, a process that would eventually leave him obsolete and forgotten.
\end{abstract}

\section{Keywords}

Early photojournalism, collective imaginary, modernisation of printing techniques

\section{Introduction: A modernising republic}

During the second half of the XIX century, Chile underwent a particularly fertile period of growth due to a convergence of several factors: the country's social order was becoming more complex with the influx of foreign migrants; the economy went through a number of booms in mining, agriculture and commerce; and transport and communication were thriving. This foundational period was all about seeking out European "models", finding the human resources and technical tools that would bring about material progress, thus achieving the apex of what was then deemed the ideal vision of the future. This led to the establishment of a modern industrial society in Chile, and paved the way for the first period of real expansion in the national economy.

The liberal economic policies that lasted until the second half of the XIX century in Chile were based on the maxim of "to produce is to move" (Álvarez, 2008), a refrain that allowed for the development and foundation of a number of media outlets. Within these new organisations, illustrated reporting became a powerful tool for promoting political agendas, social policies and international culture throughout the literate population and, although to a lesser extent, educationally marginalised areas (thanks to the presence of the illustration and the ability to reproduce thousands of copies cheaply).

This economic, political and social context was the making of lithographer Luis Fernando Rojas, whose career from the end of the War of the Pacific ${ }^{1}$ in 1883 to the mid XX century will be discussed in the following pages. At the time, photography was used principally for portrait work and typical scenes within Chilean high society. For these reasons, the work of the illustrative journalist Rojas, who drew (national and international) social classes, lifestyles, fashion and interior design and much more, provides a visual snapshot of Chilean and world history and not only as a product of literature. Unlike the latter, illustrations can be readily understood by people from all walks of life, and Rojas' lithographs were accessible to all, regardless of education or cultural background. It was uncommon at the time to find illustrators who would draw news stories or political events and, even more uncommon to see them working with historians to produce books about Chile, some of which remain authoritative to this day.

Nevertheless, the extent of Rojas' work as an illustrated historian, and his significant contribution to Chile's collective conscience, has gone unrecognised in studies of national art and design, in photojournalism,

\footnotetext{
${ }^{1}$ The War of the Pacific, also known as, was an armed conflict lasting from 1879 to 1883 that pitted Chile against the allied forces of Peru and Bolivia.
} 

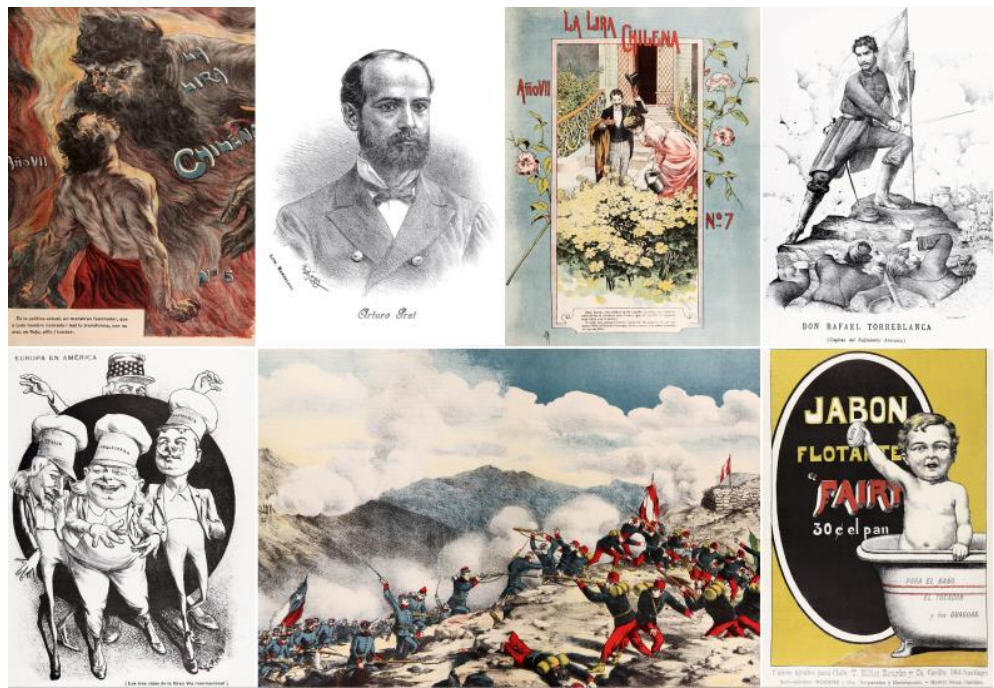

Seven areas of Rojas illustrations: Literary, portrait, historical, caricatures and Socio-political satire, adaptations of historical novels and advertisements for products in publishing, and even in national historiography.

\section{Tracing an outline of Rojas}

Luis Fernando Rojas was born in 1857 in Casablanca, to a family of very little wealth. At fourteen he was sent to Santiago in order to study at the prestigious Instituto Nacional state school. Following that, he enrolled at the Academy of Painting, and was trained by renowned teachers including: Cosme San Martín, Ernesto Kirchbach, Giovanni Mochi and Alejandro Cicarelli. From early on, Rojas stood out as an illustrator, winning Academy competitions for drawing the human form. However, after an incident with his teacher Giovanni Mochi, Rojas decided to leave the Acade-

my, and its classicist and historical legacy, to begin an autodidactic career free from links to this institution and the School of Arts and Trades. This decision effectively meant his was giving up the chance to be a "professional" artist in elite academic circles, and instead heading for a more modern and socially unrecognised trade. This is significant, as it was a golden age for the fine arts, where "artists" were highly prized and could travel to Europe to polish their skills. Of course, there was also the chance to begin a career as a graphic illustrator at a time when printing in Chile was growing steadily and the demand for lithograph artists was increasing day by day. Rojas learned the techniques of lithography as an apprentice of the renowned Alberto Saling's, and began to make a living drawing portraits. In 1875 he took the first real steps of his professional career working for "El Correo de la Exposición", a publication documenting the Santiago International Exposition, an important event for the country which showed off Chile's technological and industrial advances. At the time, the import of printing goods such as paper for new formats, more colourful inks, mobile typographical characters and lithography presses meant that printers could produce more eye-catching, original and creative publications. Rojas headed down the path of lithographic pencils, and would follow it for half a century as it wound through areas as diverse as portrait drawing in newspapers including "La ley", "El fígaro", "La lucha", "La nueva república", "Los Lunes" and others; caricatures and socio-political satire in "El Padre Cobos", "El Padre Padilla", "El cuco" and "El Poncio Pilatos"; historical drawings and journalism in books including "El álbum de la gloria de Chile", "Historia general de Chile", "Episodios nacionales" and "Diccionario biografico colonial de Chile"; adaptations of historical novels such as "La bandera negra" and "La ex-generala buendía"; literary illustrations in "La lira chilena", "La revista

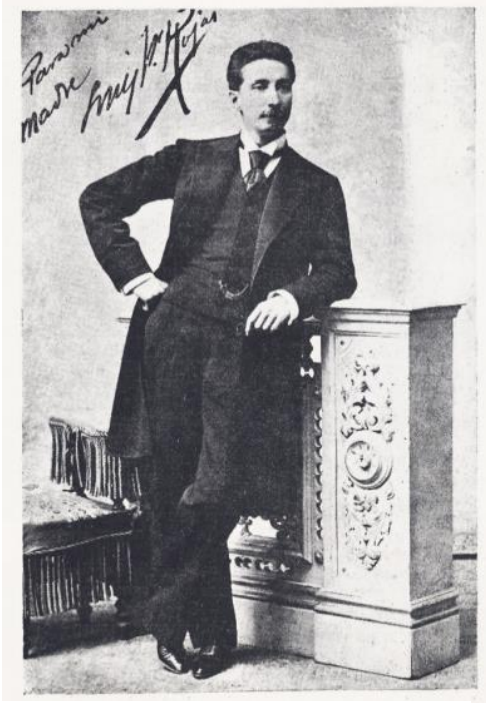

Portrait of Luis Fernando Rojas, appeared in "El Peneca" Magazine published in 1911. cómica", "sucesos" and "El corre vuela"; and a range of modern advertisements for products from cigarettes to oils, soaps and beers, all produced domestically. Furthermore, Rojas was among the first to hold the then nascent position in Chile of Artistic Director at a number of these publications. Today's designers holding similar positions can look back on Rojas as a pioneer in the history of their field in Chile.

Rojas' active presence in the national print media would lead him to work simultaneously at a number of different publications. His work was so successful that in 1895 he was able to establish Luis F. Rojas Printing and Lithographs Co., which soon was unable to keep up with printing demand and forced to close again.

Despite his humble origins, Rojas took part in a number of aristocratic events thanks to influential friends and the respect he had earned as a talented illustrator. From an early age he was close with Diego Barros Arana, a leading Chilean historian of the XIX century, due to their similar political leanings and struggle against ecclesiastical power. Likewise, he became friendly with Pedro Pablo Figueroa, José Toribio Medina and even the Nicaraguan poet Rubén 
Darío. Joaquín Edwards Bello, another important figure on Santiago's literary scene, met Rojas and singled the solitary illustrator out in his writings, calling him "the first 'people's illustrator" (Edwards, 1976).

Another key figure in Rojas' career was Benjamín Vicuña Mackenna -one of the chief driving forces behind what we could call the graphical representation of XIX century Chilean republicanism-, with whom he worked on the book "Album to the Glory of Chile", a homage to the army and navy after victory in the War of the Pacific. The book was a true pantheon of war, combining biographies of the combatants with Rojas' illustrations and a clear purpose of deifying the soldiers and sailors. Thus, Rojas became the war's principal visual historian, and he was on friendly terms with ex-combatants such as Lieutenant Colonel Eleuterio Ramírez and Enrique Phillips. This closeness, and the military's admiration for his work, led him to be named a "Veteran of 79", a symbolic recognition as a war hero with the title of "War Correspondent", a unique event in the history of Chile. It also gave him the chance to become the only civilian buried in the Military Pantheon in 1942, the year he died.

\section{Visual chronicler of Republican Chile}

Rojas was arguably the most important illustrator in Chile during the XIX century due to his participation in the creation of the "Album to the Glory of Chile", with which he established himself as a national visual historian.
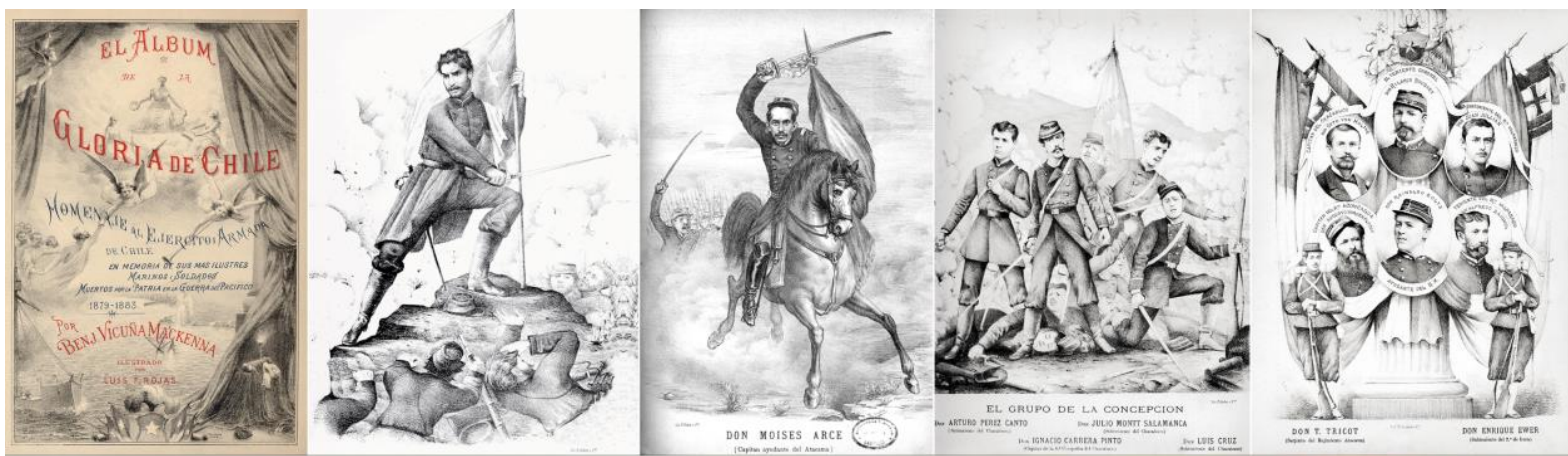

Images form the book "El Álbum de la gloria de Chile", illustrations of the heroes from the Pacific War (1883)

The War of the Pacific was a dramatic landmark in the history of South America. Indeed, it was one of the most significant wars of the XIX century, and the repercussions of the territorial changes it precipitated are still being felt in the region today -an example of this is the Bolivian demand for sovereign access to the Pacific, presented in 2015 at the International Court in The Hague.
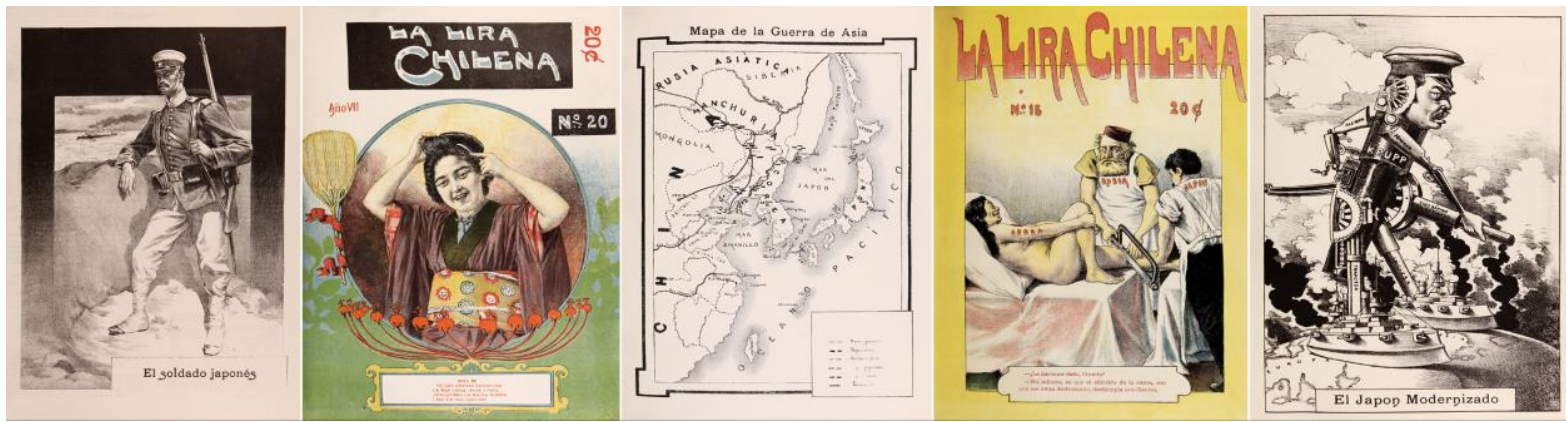

Illustrations of the Russian-Japanese war, published in La Lira Chilena, 1904

The conflict did not only result in significant territorial gains for the Chileans, but also sparked an economic boom as the country moved towards the much-awaited "national progress" and its grandiose aspirations for the future. Just like any other war, the support of the people was vital to legitimise the conflict and allow for its documentation. Rojas was the man who, using testimonials from soldiers and letters sent from the north of the country (where the battles took place), illustrated events as they unfolded. He helped to publicise the war among the people, and to give it a "face", as he sketched out in illustrations the republican sentiments of the period. Once victory was assured, he lauded the heroes and glorified the battles with chivalrous, strongly nationalist imagery, exemplifying popular feeling at the time. Rojas also sketched international navy battles. Examples of these are the numerous illustrations that he made of the Russian-Japanese war in 1904, which were published that year in La Lira Chilena. 
Russia and Japan were disputing Port Arthur which promised to become a territorial benefit, a strategic position in the Pacific Ocean, and a commercial port that would bring immense economic profit. Rojas sketching enabled Chileans to have access to images that defined the profile of the Japanese soldier, Emperor Mutsuhito, Empress Harou-ko, Geishas; and even images of the Battles of Yalu and Yentai. Even more, they included the bombardment of Port Arthur and maps that picture the development of the war. Without leaving aside his liking for political satire, Rojas created several drawings were he makes ironic comments of issues related to the war. As an example, Japan's high weaponry development; the disputing of the countries for the alleged territories, and the alliances that began to be created between the countries. Just as a reminder, for a short time Japan dominated the island of Taiwan, Port Arthur and Korea - after the Shimonoseki Treaty in 1895, the first Chinese-Japanese war from 1894 to 1895 -, but after the Russian intervention, Germany and France forced Japan to return Port Arthur and Manchuria in China. In 1905, and after its victory, Japan consolidated as a world power.

At the same time as Rojas was drawing his war pictures, he was also entrusted with the work of varied extensive important books of the History of Chile, working with distinguished historians of the time, such as: Diego Barros Arana, José Toribio Medina, and Pedro Pablo Figueroa among others. These became key publications in Chilean Historiography, depicting the stages of Chile during the Conquest, the Colony, Independence and the Republic.

Another especially significant book in which Rojas participated was Armando Silva's "Episodios Nacionales" (National Events), published in 1942. The book recounted 150 important events in the history of Chile, starting with the origins of the Inca Trail and culminating in the Alpatacal rail disaster of 1927. It has become part of the library of the annals of Chile, and as such is a rich source of information on national events throughout four centuries of Chilean history, illustrated in its entirety in black and white by Rojas. Moreover, the book was approved
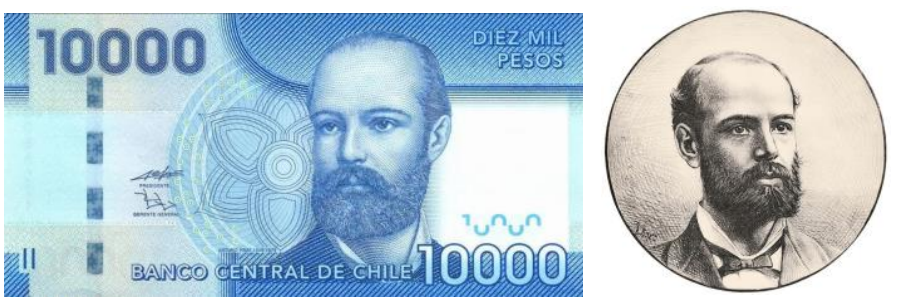

At the left of the page, the Chilean actual banknote with the portrait of Arturo Prat Chacón inspired in the original Rojas's illustration in the right. This image was published in "Taller Illustrado" newspaper in

1886.
importance even towards the end of his life. His work as maintained a certain degree of portant moments in the nation's history stirred popular feelings of respect and admiration towards the same patriotic symbols that would later be used on stamps and bank notes.

Rojas made full use of patriotic ideals, but at the same time he also turned his critical eye towards the poverty and destitution of the people contrasted with the privilege and customs of the creole elite. His in situ registry of the daily life of country folk, landowners, dandies and city dwellers was a faithful representation of the social and economic transformations of the end of the XIX century.

\section{Final thoughts: The disappearance of a master}

This essay is based on the book "Luis Fernando Rojas Obra Gráfica: 1875-1942 " (The Graphic Works of Luis Fernando Rojas: 1875-1942), which is the only publication to date that has attempted to describe the artist's work as the first Chilean visual historian. Although there had been two exhibitions of his work, they were of little impact and there are no records available, meaning the artist is still almost entirely unknown. Only in 2014, with the launch of this book, did the over 155 year-old debt to this great man for his services to the country, and national and international history begin to be repaid. By means of his sketches, relevant milestones and events taking place around the world became available to Chileans as images of what was happening. One might question how real or true these images were, but it is a debate which is set inasmuch for photography, audiovisual records and news in social media.

\footnotetext{
${ }^{2}$ Book published in 2014 by LOM Ediciones. Authors: Carola Ureta and Pedro Álvarez.
} 
Rojas worked actively for more than sixty years across a range of different genres of illustration. Nonetheless, perfections in the printing process and journalistic genres caused an acceleration in supply that was to adapt to the ephemeral nature of daily news printing, making publications strictly production oriented. Likewise, the incorporation of the modern and mechanised technique of photography sparked a collapse in the manual illustration industry, especially in newspapers and magazines. This transformation in the design and format of print media had a direct influence in the trailing off of Rojas' career. In spite of everything, he continued to work as a freelance illustrator instead of an artistic. Nevertheless, he ought to be considered a pioneer in that he was one of the first to occupy this kind of role in Chile, a role that, even today, is so important in the fields of design, marketing, publishing, photography and audio-visual production.

The arrival of new foreign illustrators, alongside the appearance of new Chilean caricature artists trained at the modern Zig-Zag magazine, also contributed to Rojas vacating his position as Chile's leading illustrator, and he was not hired by any more magazines or newspapers after the first few years of the XX century. To some extent, Rojas had become typecast as an illustrator of historical events and battles after his work with Vicuña Mackenna, and he was no longer considered for other kinds of illustration.

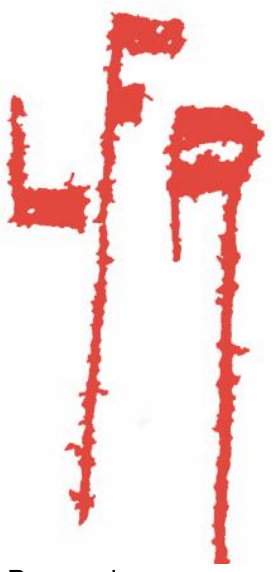

Personal monogram used by Luis Fernando Rojas to sign many of his illustrations and lithographs.

The fact that he renounced the Academcy of fine Arts, and the decision to become selfeducated, set him apart from his teachers and the academic world; and so, there are few references about him in books or studies about the history of Art in Chile, even though he was known as the "greatest illustrator of the time" (Pereira, 1992, p.267). Rojas' drawings certainly incorporated the reigning Victorian aesthetics of the period, taking as referents Honoré Daumier, J.J. Grandville and Paul Gavarni, and were also influenced by the bourgeois and French-style Art Nouveau typical of the transition from Romanticism to Modernism. However, despite his external influences, Rojas came to carve out his own style and was one of the first Chilean artists to incorporate the so-called "Chileanity" into his work. By drawing all of the social strata of the XIX century, Rojas contributed to the construction of a national identity. In any case, his style was consistently realist thanks to the job offers he was apt to receive.

Similarly, the period also saw conditions emerge for the beginning of mass access to culture, which in turn encouraged material progress. Cultural diffusion went beyond the printed word for the first time with the advent of radio. This backdrop of technological transformation in the publishing industry, added to the economic crisis of 1929, meant that the demand for illustrated publications dropped off sharply, and Rojas' productivity with it.

Unfortunately, neither before nor after his death did Rojas receive any kind of significant recognition -from his peers or the authorities- for his extensive work as a visual historian of colonial to interbellum Chile. It seems paradoxical that having defended national interests during the War of the Pacific and guaranteed the protection of economic interests in the area of conflict that came to represent the country's progress, it was this very progress that led to Rojas' obsolescence as he was left out in the cold by innovative printing techniques. Although Rojas was a skilled lithographer, the arrival of photoengraving in Chile pushed him out of publishing circles and into obscurity. Nevertheless, his work is still alive in the collective conscience of Chilean history permitting history to become fixated in images which depict national and international events.

Just as an article published in Mapocho magazine points out: "Rojas was a man who became part of our national heritage, and gave the impression of being a living breathing national monument" (Ojeda, 1994).

\section{References}

Álvarez, P. (2008) Chile marca registrada, Historia general de las marcas comerciales y el imaginario del consumo en Chile, Santiago: Ocho Libros Editores-Universidad del Pacífico.

Edwards, J. (1976) Crónicas del tiempo Viejo, Santiago: Editorial Nacimiento.

Ojeda, O. (1994) “El dibujante Rojas”, Revista Mapocho, vol. 35, first semestre, pp. 374.

Pereira, E. (1992) Estudios sobre la historia del Arte en Chile Republicano, Santiago: Universitaria.

\section{Biographical note}

Carola Ureta (1988) designer Pontificia Universidad Católica de Chile and ( ) Magister Cultural Management. In 2014 publishes the book Luis F. Rojas Obra Gráfica: 1875-1942. Works on research projects, heritage rescue and academic in Design schools in Santiago. In 2015, attended the VI Latin American Congress on Education Design, Argentina. 